\title{
Toll-like receptor signal transduction
}

\author{
Jayalakshmi Krishnan ${ }^{1}$, Kumar Selvarajoo ${ }^{2}$, \\ Masa Tsuchiya ${ }^{2}$, Gwang Lee ${ }^{1,3}$ \\ and Sangdun $\mathrm{Choi}^{1,4,5}$
}

${ }^{1}$ Department of Molecular Science and Technology

Ajou University

Suwon 443-749, Korea

${ }^{2}$ Institute of Advanced Biosciences

Keio University

Yamagata 997-0035, Japan

${ }^{3}$ Brain Disease Research Center

Ajou University School of Medicine

${ }^{4}$ Department of Biological Sciences

College of Natural Science, Ajou University

Suwon 443-749, Korea

${ }^{5}$ Corresponding author: Tel, 82-31-219-2600;

Fax, 82-31-219-1615; E-mail, sangdunchoi@ ajou.ac.kr

Accepted 2 July 2007

Abbreviations: CpG-ODN, synthetic oligodeoxyribonuclotides containing CpG motifs; CRP, C reactive protein; DC, dendritic cells; DOK1, downstream of kinase 1; GARG 16, glucocorticoid- attenuated response gene 16 product; IAQ, imidazoquinolines; IKK, I $\mathrm{B}$ kinase; IKKE, IКB kinase epsilon; IP-10, interferon activated gene 10; IRAK4, interleukin 1 receptor-associated kinase 4; IRF, interferon regulatory factor; LBP, lipopolysacchride binding protein; LRR, leucine rich repeat; LTA, lipoteichoic acid; MAL, MyD88 adapter like; MALP2, macrophage-activating lipopeptide 2; MBL, mannose binding lectin; MDA5, melanoma differentiation-associated gene 5; MMTV, mouse mammary tumor virus; MyD88, myeloid differentiation primary response gene 88; NALP, NACHT, leucine rich repeat and PYD containing; NOD1, nucleotide-binding oligomerization domain protein 1; OAS, 2,5-oligoadenylate synthetase; PAM2CSK4, synthetic diacylated lipopeptide Pam 2 Cys-SKKKK $\times$ 3 TFA; PAM3CSK4, synthetic triacylated lipopeptide $\mathrm{Pam}_{3} \mathrm{Cys}$ SKKKK $\times 3 \mathrm{HCl}$; PAMP, pathogen associated molecular pattern; pDC, plasmacytoid dendritic cells; PI3K, phosphatidylinositol 3kinase; PIP2, phosphatidylinositol 4,5-bisphosphate; PMN, polymorphonuclear phagocytes; Poly-IC, polyinosinic-polycytidylic acid; PRR, pattern-recognition receptor; PTX3, pentraxin 3; RANTES, regulated upon activation, normal $\mathrm{T}$-cell expressed, and secreted; RIG1, retinoic acid inducible gene 1; SAP, serum amyloid protein; sE-selectin, soluble form of E-selectin; SHIP, SH2-containing inositol phosphatase; sICAM, soluble intercellular adhesion molecule; SOCS1, suppressor of cytokine signaling 1; SR, scavenger receptor; ssRNA, single stranded RNA; ST2, suppression of tumorigenicity 2; TBK1, TANK-binding kinase 1; TIR, Toll/interleukin-1 receptor; TLRs, Toll-like receptors; TRAF6, tumor necrosis factor receptor-associated factor 6; TRAM, TRIF-related adapter molecule; TRIF, TIR domain-containing adapter protein inducing IFN- $\beta$; VSV-G, vesicular somatitis virus G protein; ZYM, zymosan

\begin{abstract}
Toll-like receptors (TLRs) are the archetypal pattern recognition receptors in sensing exogenous pathogens. Activation of TLRs is a first line of defense of the immune system, leading to the activation and recruitment of neutrophils and macrophages to sites of infection and enhances antimicrobial activity. The TLR signaling through different intracellular molecules, such as MAP kinases and $I_{\kappa} B$ kinases which are conserved signaling elements for many receptors, leads to a distinct set of proinflammatory gene expressions. However, how these pathways differentially and precisely control the transcription of identical genes remains largely unknown. Our review focuses on the details of up-todate signaling molecules including negative regulators and their role in controlling innate immune response. We also stress the importance of developing systemic approaches for the global understanding of TLR signaling so that appropriate drug therapeutic targets can be identified for regulating inflammatory diseases.
\end{abstract}

Keywords: immunity, natural; ligands; signal transduction; systems biology; Toll-like receptors

\section{Introduction}

Toll-like receptors (TLRs) are closely related type I transmembrane proteins, which form the major pattern-recognition receptors (PRRs) to transduce the signals in response to microbial intruders such as protozoa, bacteria, fungi and viruses (Takeda and Akira, 2005). The signal transduction pathways that are activated downstream of TLRs have been the subject of intensive analysis by numerous laboratories (Fitzgerald et al., 2003; Kawai et al., 2004; McDonald et al., 2006). The continued focus of research on TLR signaling has provided a lot more information on pathways activated by TLRs, and new layers of complexity and regulation have been revealed. Stimulation of TLRs underpins the activation of several aspects of innate and adaptive immune responses via cytokines, type I interferons, chemokines, cell surface molecules and chemokine receptors, increases effector functions such as phagocytosis, and enhances capacity to present antigen to T cells (Sioud, 2005). Although TLRs are crucial for innate immunity, they are also prerequisite for the induction of adaptive immune responses in combating many infections. The pur- 
pose of this review is to discuss TLR signal transduction, including adapter molecules, negative regulators, and transcription factors.

\section{TLR structure, location and ligands}

\section{TLRs are bona fide 'pattern recognition' receptors}

The conserved patterns unique to microbial surface are called pathogen associated molecular patterns (PAMPs), that allow the cell to recognize dangerous non-self molecules from self-molecules. Cells contain unique PRRs like TLRs to fight against the foreign intruders. PRRs handle the microbial infection and they are broadly distributed in various cells of the immune system, which include polymorphonuclear phagocytes (PMN), monocytes/macropahges, dendritic cells, natural killer cells as well as mucosal epithelial and endothelial cells (Becker et al., 2000; Cario et al., 2000; Muzio et al., 2000; Faure et al., 2001; Visintin et al., 2001). Recognition of PAMPs results in activation of macrophages, leading to a plethora of biological responses required for eliciting both the innate and adaptive arms of the immune response, and they are distributed all over the body (Table 1). TLRs are highly conserved through evolution and its presence is reported as low as the phylum from Porifera which includes sponges (Wiens et al., 2005). Toll was first discovered in
Drosophila. Researches working in the mechanisms mediating embryonic development in Drosophila found a remarkable sequence similarity between Toll, a transmembrane protein involved in embryogenesis, and the human interleukin-1 receptor (IL-1R) (Hashimoto et al., 1988; Gay and Keith, 1991) which is discussed in the following paragraph.

\section{Structural similarity with interleukin-1 receptor (IL-1R)}

TLRs belong to a superfamily called the Toll/LL-1 receptor (TIR) family and all members of which contain cytoplasmic TIR domains. The endodomain of all TLRs differs from IL-1R ectodomain in which TLR has leucine rich repeats (LRRs) whereas IL-1R posses Ig-like domains. The cytoplasmic region of TLRs shares a stretch of TIR domain, which mediates homo- and heterophilic interactions between TLRs and TIR-containing adapters (Akira et al., 2001). The TIR domain is approximately 160 amino acids long and is essential for cellular signaling, and contains three regions of particular importance, termed boxes 1,2 and 3 , although regions outside these boxes also show conservation. Box 1 is the signature sequence of the TIR domain. Box 2 forms an important loop in the structure, which probably engages with downstream elements (or with

Table 1. Representation of pattern recognition receptors (PRRs) in body fluids, cell membrane and cytoplasm.

\begin{tabular}{lccc}
\hline \multicolumn{1}{c}{ Body fluids } & Cell membrane & Cytoplasm & Endogenous \\
\hline LBP & Plasma membrane & Antibacterial & SR \\
Pentraxin family members & TLR1 & NOD-like receptor & CD36 \\
SAP, CRP, PTX3 & TLR2 & Antiviral & NALP3 \\
MBL, C1q, C3 & TLR4 & RIG1 & MDA5 \\
& TLR5 & PKR & OAS \\
& TLR6 & & \\
Endosomes & TLR3 & & \\
& TLR7 & &
\end{tabular}

PAMPS are opsonized by the PRRs present in the body fluids. LPS is captured by LPS binding protein (LBP) in blood (Ulevitch and Tobias, 1995). Complement pathways are activated by mannose binding lectin (MBL), pentraxin family members serum amyloid protein (SAP), $C$ reactive protein (CRP) and pentraxin 3 (PTX3) (Gasque, 2004, Garlanda et al., 2005) and also by complement components C3 and C1q (Gasque, 2004). TLR1, 2, 4, 5, and 6 are in plasma membrane and TLR3, 7, 8, and 9 are in endosomes, respectively. The cytoplasmic PRRs can be classified into antibacterial, antiviral and endogenous ligand recognizers. NOD1 (Nucleotide-binding oligomerization domain protein 1) and NOD2 recognize peptidoglycan derived peptides, $\gamma$ -D-glutamyl-meso-diaminopimelic acid (iE-DAP) (Chamaillard et al., 2003) and muramyl dipeptide (MDP) (Girardin et al., 2003; Inohara et al., 2003), respectively. Antiviral detectors include retinoic acid inducible gene 1 (RIG1), melanoma differentiation-associated gene 5 (MDA5, also called as Helicard) and 2-5-oligoadenylate synthetase $1 \mathrm{~A}$ (OAS) (Stark et al., 1998). Scavenger receptor (SR) and CD36 can mediate phagocytosis of apoptotic cells, whereas NALP3 (NACHT, leucine-rich repeat and PYD containing 3) can recognize endogenous danger signals such as extracellular ATP (Taylor et al., 2005; Mariathasan et al., 2006). 
another TLR because TLRs appear to dimerize during signaling). Most TIR Box 2 sequences have a conserved proline, which when mutated to histidine renders the protein unable to signal. The function of Box 3 is not fully understood, although it contains residues important in signaling (based on mutational analysis of the type I IL-1 receptor) (Slack et al., 2000) (Figure 1).

\section{Types of TLRs and their location in the cell}

In mammals, to date, 13 TLRs (Roach et al., 2005) with distinct specificities to recognize highly conserved structural motifs of microbial pathogens as well as several host-derived molecules (Akira and Takeda, 2004) have been identified. The specific locations of TLRs remain unclear. For example, the first group (TLRs 1, 2, 4, 5 and 6) are found at the plasma membrane. The second group (TLRs 3,7 , 8 and 9) are intracellular and likely signal from acidic endosomes (Figure 2). According to Barton

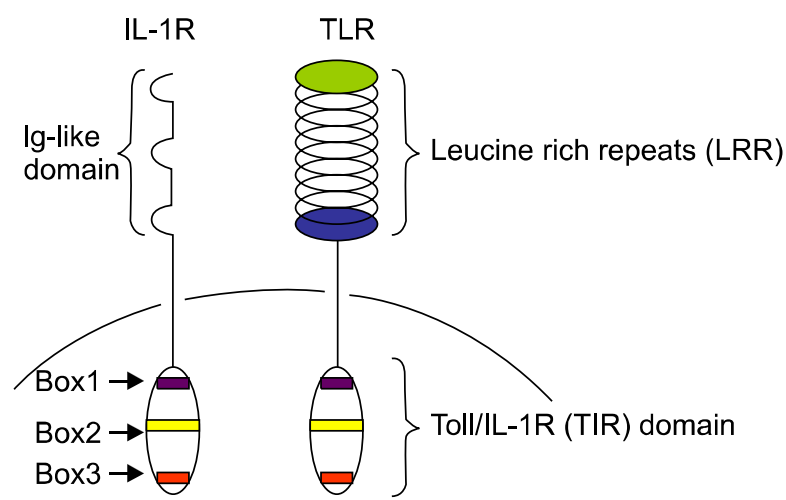

Figure 1. High level structural similarity between IL-1R and TLR. Both receptors differ in their extracellular domain, in which IL-1R possesses Ig-like domain, whereas TLR has leucine rich repeats (LRR). The intracellular region is the same, which contains Toll/L-1R (TIR) domain indicating the high level signaling similarity between the receptors.

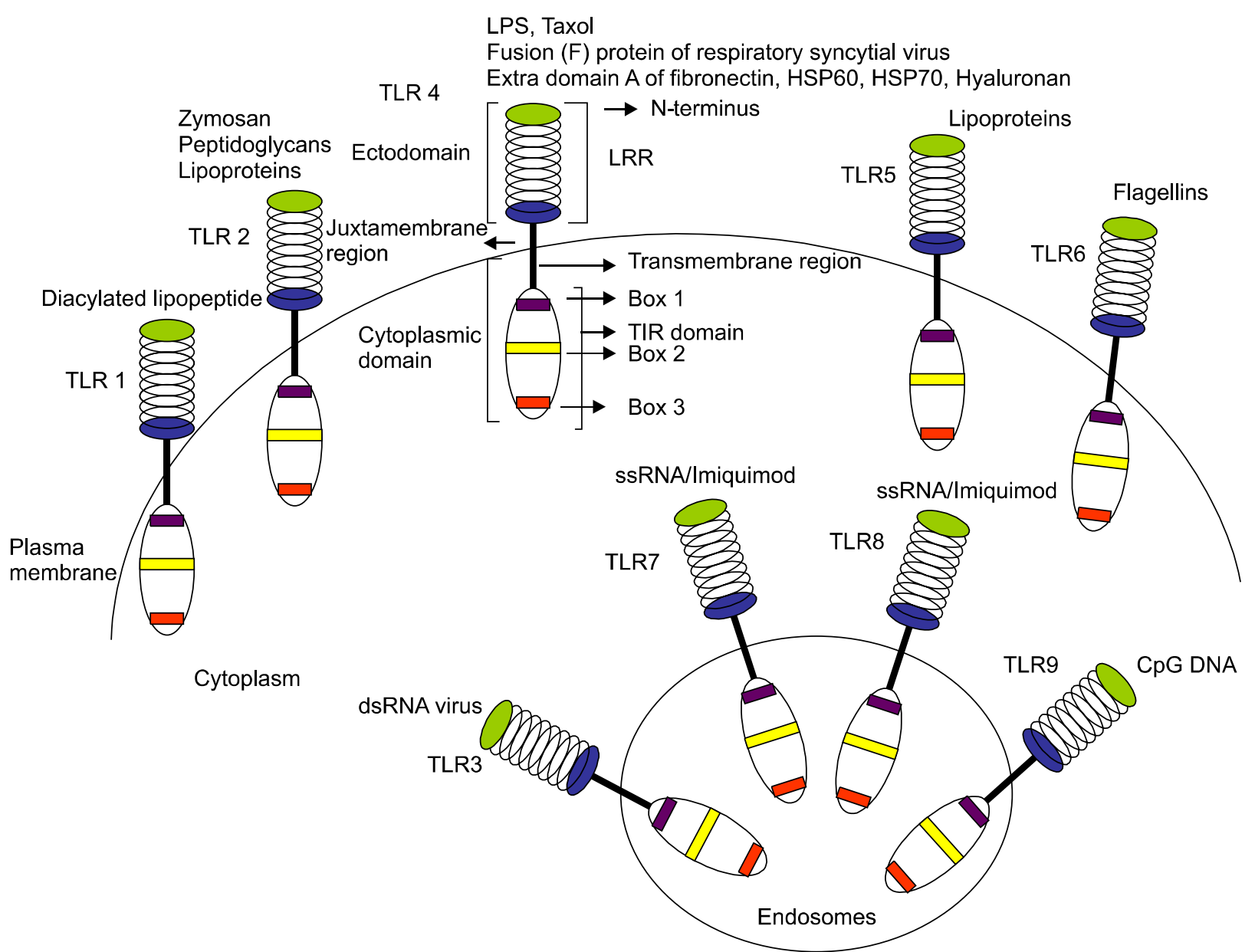

Figure 2. The localization of TLRs in the cell. TLRs on the plasma membrane include TLR 1, 2, 4, 5 and 6. TLRs which are present on the endosomal membrane include TLR 3, 7, 8 and 9. 
et al. (2006), the subcellular localization is of great importance for the discrimination of viral nucleic acids from self nucleic acids. In a chimeric experiment of TLR9 ectodomain and TLR4 endo- and transmembrane domain they showed that these hybrids responded to self nucleic acids when present at plasma membrane but TLR9 in the endosomes responded only to foreign nucleic acids. They concluded that the localization of the nucleic acid-sensing TLRs is critical in discriminating between self- and nonself nucleic acid.

\section{Ligands of TLRs}

We classified the known mammalian Toll-like receptors with the adapters recruited, location, species and the ligands which stimulate TLRs (Table 2). TLR4 has been genetically identified as a signaling molecule essential for the recognition of LPS, a component of Gram-negative bacteria (Poltorek et al., 1998; Hoshino et al., 1999). Individual TLRs can recognize several structurally unrelated ligands. For example, TLR4 recognizes not only LPS but also taxol (Kawasaki et al., 2000), fusion ( $F)$ protein of respiratory syncytial virus (Kurt-Jones et al., 2000), extra domain A of fibronectin (Okamura et al., 2001), heat shock protein (HSP) 60 (Ohashi et al., 2000), HSP 70 (Habich et al., 2002), and hyaluronan (Taylor et al., 2004, 2007). It is important to understand how TLR4 recognizes these structurally unrelated ligands. TLR2 responds to mycobacteria, yeast cell wall component zymosan, and Gram-positive bacteria (Takuechi et al., 1999; Underhill et al., 1999a, b; Takuechi et al., 2000,). TLR6 associates with TLR2 and recognizes lipoproteins from mycoplasma (Ozinsky et al., 2000). TLR5 mediates the induction of the immune response by bacterial flagellins (Hayashi et al., 2001).

Recent studies showed that ssRNA is the natural ligand for TLR7/8 (Hemmi et al., 2000; Diebold et al., 2004; Heil et al., 2004). Activation of innate immunity by siRNAs is sequence dependent and occurs mainly in immune cells that express functional TLR7/8 (Hornung et al., 2005; Judge et al., 2005; Sioud, 2005, 2006). Consistent with the role of endosomal TLRs in siRNA sensing, TLR7 knockout mice did not mount immune activation in response to siRNAs (Hornung et al., 2005). A synthetic compound (imidazoquinoline compound R848) with antiviral activity has been described as a ligand for TLR7 and TLR8 (Thomassen et al., 1999; Hemmi et al., 2002; Jurk et al., 2002). TLR9 has been shown to recognize unmethylated bacterial CpG DNA (Hemmi et al., 2000) and TLR3 recognizes double stranded RNA (dsRNA) (Alexopoulou et al., 2001). TLR11 is involved in the recognition of uropathogenic bacteria (Zhang et al., 2004). The natural ligands for TLRs 10, 12 and 13 are still not known.

Immunostimulatory siRNA can also induce the maturation and differentiation of monocytes into

Table 2. TLRs and their ligands.

\begin{tabular}{|c|c|c|c|c|}
\hline TLRs & Adapters & Location & Species & Ligands \\
\hline TLR1 & MyD88/Mal & Cell surface & Human/Mouse & PAM3CSK4 \\
\hline TLR2 & MyD88/Mal & Cell surface & Human/Mouse & PAM2CSK4, MALP2, LTA, ZYM \\
\hline TLR3 & TRIF & Cell compartment & Human/Mouse & $\begin{array}{l}\text { dsRNA, Poly-IC, viral RNA, } \\
\text { siRNA, endogenous mRNA }\end{array}$ \\
\hline TLR4 & MyD88/Mal/TRIP/TRAM & Cell surface & Human/Mouse & $\begin{array}{l}\text { LPS, MMTV, VSV-G, Taxol, } \\
\text { F protein, Fibronectin, HSP60, } \\
\text { HSP70, Hyaluronan }\end{array}$ \\
\hline TLR5 & MyD88 & Cell surface & Human/Mouse & Flagellins \\
\hline TLR6 & MyD88/Mal & Cell surface & Human/Mouse & MALP2, LTA, Zym \\
\hline TLR7 & MyD88 & Cell compartment & Human/Mouse & ssRNA, IAQ (R848) \\
\hline TLR8 & MyD88 & Cell compartment & Human/Mouse & ssRNA, IAQ (R848) \\
\hline TLR9 & MyD88 & Cell compartment & Human/Mouse & CpG-ODN \\
\hline TLR10 & Unknown & Cell surface & Human & Unknown \\
\hline TLR11 & MyD88 & Cell surface & Mouse & Profilin \\
\hline TLR12 & Unknown & Unknown & Mouse & Unknown \\
\hline TLR13 & Unknown & Unknown & Mouse & Unknown \\
\hline
\end{tabular}

CpG-ODN, synthetic oligodeoxyribonuclotides containing CpG motifs; IAQ, imidazoquinolines, including resiquimod and imiquimod; LTA, lipoteichoic acid; MAL, MyD88 adapter-like; MALP2, macrophage-activating lipopeptide 2; MMTV, mouse mammary tumor virus; PAM3CSK4, synthetic triacylated lipopeptide Pam ${ }_{3}$ Cys-SKKKK $\times 3$ HCl; PAM2CSK4, synthetic diacylated lipopeptide Pam ${ }_{2}$ Cys-SKKKK $\times 3$ TFA; Poly-IC, polyinosinic-polycytidylic acid; ssRNA, single stranded RNA; VSV-G, vesicular somatitis virus G protein; ZYM, zymosan. 
macrophages, dendritic cells, and human bone marrow $\mathrm{CD} 34^{+}$progenitor cells, in addition to the induction of cytokines and interferons (Sioud et al., 2006). Thus, signaling via TLRs not only induces cytokine production against the invader but it can also induce immune cell maturation for effective immune responses. TLRs contribute to both the war against the invader as well as the maturation of important immune cells. The identification of endogenous compounds like HSPs and fibronectin have also been recognized by TLRs, leading to the suggestion that TLRs might also act as danger sensing receptors rather than just being involved in microbial recognition as the aforementioned proteins can also be autoantigens. Many types of cells also have TLR-independent, intracellular detection systems to sense viral invasion and initiate innate immune responses.

\section{Adapter proteins recruited by TLRs}

\section{TLR mediated MyD88-dependent and independent cellular signaling}

For the last one decade, how PRRs convert the message gleaned from recognition of a pathogen into an appropriate cellular response has been the subject of intensive investigation. The signaling pathways activated by TLRs are broadly classified into MyD88-dependent and independent pathways (Takeda and Akira, 2005) as MyD88 is the universal adapter protein recruited by all TLRs except TLR3. The major pathways activated by TLR engagement are passed through $I_{\kappa} B$ kinase (IKK), MAPK and phosphatidylinositol 3-kinase (PI3K)/ Akt pathways. These pathways regulate the balance between cell viability and inflammation.

The signaling pathways activated by a specific TLR are largely dictated by the adapter proteins

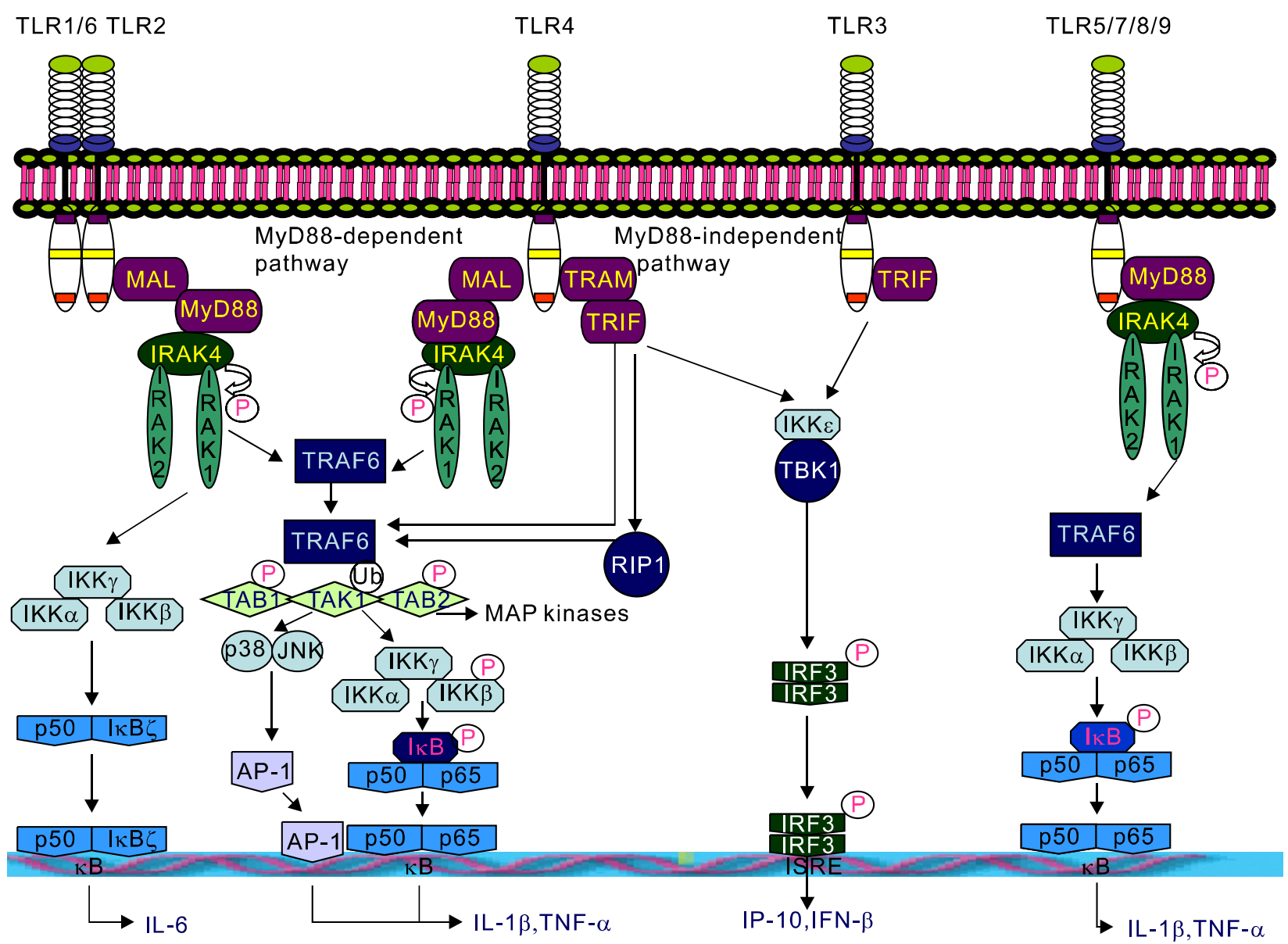

Figure 3. Signaling mediated by TLR is broadly classified as MyD88-dependent and independent pathways. All TLRs utilize MyD88 with the exception of TLR 3. TLR 7, 8 and 9 pathways are predominant in pDCs. MyD88 binds with the TIR domain of the receptor and phosphorylates IRAK4 which in turn phosphorylates IRAK1. IRAK1 phosphorylates TRAF6 leading to the ubiquitination of TAK complex. Activation of IKK, JNK and p38 pathways leads inflammatory and antiviral responses. ISRE, interferon stimulatory response element; $\kappa B, \kappa B$ site; $p$, phosphorylation; ub, ubiquitination. 
recruited to the intracellular domain of the TLR upon ligand binding (Akira and Takeda, 2004). There are currently four cytosolic adaptor proteins that are thought to play a crucial role in specificity of individual TLR-mediated signaling pathways. Amongst them, TLR4 signaling involves all four adapter proteins, MyD88 (myeloid differentiation primary response gene 88 ), MyD88 adapter like [MAL; also known as TIRAP (TIR domain-containing adapter protein)], TIR domain-containing adapter protein inducing IFN- $\beta$ [TRIF; also known as TICAM1 (TIR domain-containing adapter molecule 1)], and TRIF-related adapter molecule [TRAM; also known as TICAM2 (TIR domain-containing adapter molecule 2)] (McGettrick and O'Neill, 2004). The differential recruitment of these adapter proteins by different TLRs form the basis for the specificity in the signaling process activated by them. Our current understanding about TLR signaling is illustrated in Figure 3.

\section{MyD88 is the primary adapter for microbial signaling}

Every TLR member differentially utilizes adapters, but MyD88 (296 amino acid protein) seems to be the widely used adapter molecule. MyD88 harbors a TIR domain as well as a death domain. The carboxy terminal of TIR domain interacts with the cognate domains in the cytoplasmic tails of the TLRs, and the amino terminal death domain mediates the interaction with the corresponding domain of interleukin 1 receptor-associated kinase 4 (IRAK4) (Wesche et al., 1997; Li et al., 2002). MyD88 was originally isolated as a myeloid differentiation primary response gene that is rapidly induced upon IL-6 stimulated differentiation of M1 myloleukemic cells into macrophages (Lord et al., 1990). MyD88 $^{-/}$mice were resistant to LPSinduced shock compared to that of wild type (Kawai et al., 1999) that provided an invaluable tool for analyzing the critical role of MyD88 in TLR signaling. However, LPS is still capable of activating NF- $\mathrm{BB}$ and MAPK in MyD88-deficient mice, and this activation in MyD88-deficient cells is delayed in reaching a peak in comparison with wild-type cells (Kawai et al., 1999). Importantly, LPS can induce IFN- $\beta$ production by macrophages and DCs (dendritic cells) in a manner independent of MyD88 (Kawai et al., 2001). Further studies pointed out that MyD88 ${ }^{---}$mice still can produce type I interferon inducible gene products such as IP-10 and GARG 16 (Kawai et al., 2001). Together, these observations suggested other adapters mediate late activation of NF- $\mathrm{KB}$ and MAPK which is associated with type I IFN induction in TLR4 signaling.

\section{MAL specificity in TLR signaling}

MAL has been identified as an adapter molecule that mediates responses to TLR2 and TLR4 ligands (Equils et al., 2004). Although MAL has similarities to MyD88, it differs in N-terminal portion in which MAL is 75 amino acids shorter and lacks a death domain (Fitzgerald et al., 2001). MAL is utilized by a subset of TLRs that signal from the plasma membrane but not by TLRs that signal from endosomes. Recently, Kagan and Medzhitov (2006) found that MAL resides on membranes that shuttle between the plasma membrane and endosomes by an ADP ribosylation factor 6 (ARF6) dependent processes. They further demonstrated that MAL contains a phosphatidylinositol 4, 5-bisphosphate (PIP2) binding domain that mediates $M A L$ recruitment to membranes and is required for TLR4 signaling. Therefore, the primary function of $M A L$ in TLR signaling seems to control the recruitment of MyD88 to TLR4. They proposed that the unique phosphoinositide composition of cellular membranes dictates differential adapter recruitment to TLRs residing in different compartments. MAL and MyD88 together may be required for a rapid and optimal response. Surprisingly, $\mathrm{MAL}^{-/-}$ mice also displayed impairment in TLR2-mediated responses, suggesting $M A L$ as an important component of TLR2-mediated innate host defense (Horng et al., 2002). Studies with MAL gene targeted mice revealed that $M A L$ functions in the MyD88-dependent NF- $\mathrm{B}$ activation pathway shared by TLR2 and TLR4 (Horng et al., 2002; Yamamoto et al., 2002).

\section{Adapters mediating MyD88-independent signaling}

Most of the TLRs seem to be absolutely dependent on the expression of MyD88 for all of their functions whereas TLR3 and TLR4 are unique in their ability to activate MyD88-independent responses. TLR3 and TLR4 appear to have evolutionarily diverged from other TLRs to activate gene expression programs and trigger antiviral responses by a mechanism involving the activation of IRF3. MyD88-independent signaling events are controlled by TRIF (for TLR3) or TRIF/TRAM (for TLR4) and induce IRF3-dependent type I interferon production (Fitzgerald et al., 2003; Hoebe et al., 2003; Oshiumi et al., 2003; Yamamoto et al., 2003a, b) (Figure 3).

\section{TIR domain containing adapter inducing interferon- $\beta$ (TRIF) and TRIF related adapter molecule (TRAM)}

TRIF is an adapter for TLR3 and TLR4, and is associated with the MyD88-independent cascade. 
TRIF was identified through database searches and has 712 amino acids (Yamamoto et al., 2002, 2003a). TRIF was found to be primarily associated with virus infections owing to the induction of IFN- $\alpha$ and IFN- $\beta$ (Yamamoto et al., 2002). However, there are studies which show the role of TRIF in bacterial infection. TRIF ${ }^{-/}$mice infected with $E$. coli display attenuated neutrophil migration and attenuated production of NF- $\kappa B$, TNF- $\alpha$ and IL- 6 , and LPS induced $\mathrm{C}-\mathrm{X}-\mathrm{C}$ chemokines in the lungs (Jeyaseelan et al., 2007). Another in vitro study using TLR3 ligands suggests that TRIF regulates three distinct signaling pathways leading to IRF3 activation, NF- $\kappa \mathrm{B}$ activation, and apoptosis via a RIP/FADD/ caspase 8-dependent pathway (Han et al., 2004). Two noncanonical IKB kinases (IKKs), TBK1 (TANK-binding kinase 1 ) and IKK $\varepsilon$ ( $\mathrm{I}_{\kappa} \mathrm{B}$ kinase $\varepsilon$ ), interact with TRIF, activate IRF3/IRF7 and finally lead to IFN- $\beta$ production (Fitzgerald et al., 2003).

TRAM (253 amino acids) was identified as a small TIR domain containing protein (Bin et al., 2003). TRAM is placed upstream of TRIF in the induction of IFN- $\beta$ through MyD88-independent pathway. The role of TRAM in LPS signaling appears to act as a bridging adapter connecting TLR4 and TRIF. In TRAM deficient mice, normal inflammatory cytokine production induced by TLR2, TLR7 and TLR9 ligands was observed (Yamamoto et al., 2003b). TLR4 mediated phosphorylation of IRAK was induced normally, indicating that activation of the MyD88-dependent pathway was unaffected.

\section{Kinases involved in signaling from adapters to transcription factors}

\section{Downstream of TLR signaling by adapters are mediated by IRAK family}

The next component of downstream TLR signaling is the IRAK family members. IRAKs are important mediators in the signal transduction of the TLR family as they may act to potentiate the downstream signaling. So far, four IRAKs have been identified, such as IRAK1, IRAK2, IRAK4 and IRAKM. IRAK1 and IRAK4 possess intrinsic serine/ threonine protein kinase activities, whereas IRAK2 and IRAKM lack this activity, that may negatively regulate TLR mediated signaling. IRAKM deficient cells show hyperproduction of inflammatory cytokines in response to various TLR ligands (Suzuki et al., 2002). IRAK4 deficient mice also show no response to a variety of bacterial components suggesting the critical involvement of IRAK4 in TLR signaling (Suzuki et al., 2002). IRAK1 has three TRAF6 (tumor necrosis factor receptorassociated factor 6 ) binding motifs to mediate the interaction with TRAF6 (Ye et al., 2002) and undergoes autophosphorylation. LPS responses were not diminished in IRAK2 deficient mice, indicating the kinase activity of IRAK2 is not required for downstream signaling events ( $\mathrm{Li}$ et al., 2002). Upon stimulation, IRAK4 and IRAK1 are sequentially phosphorylated and dissociated from MyD88, which results in activation of TRAF6 (Figure 3).

\section{TRAF6 is the central activator of MAPK during microbial infection}

TRAF6 belongs to an E3 ubiquitin ligase family, which facilitates the synthesis of lysine 63 linked polyubiquitin chains (Chen, 2005). TRAF6 is the activator of canonical NF- $\mathrm{KB}$ pathway (Hayden and Ghosh, 2004). TRAF6 is ubiquitinated at K63 chains and this $\mathrm{K} 63$ polyubiquitinated TRAF6 mediates activation of the next component in the pathway, which is most likely to be TGF- $\beta$ activated kinase-1 (TAK1) (Sun et al., 2004). In fact, the TAK1 associated proteins, TAB2 and TAB3, contain a domain that interacts specifically with K63-ubiquitin chains. This model for TLR signaling predicts that the TAK1-TAB complex associates with K63-ubiquitinated TRAF6 to activate TAK1 kinase, which then activates the IKK complex as well as the JNK kinases. Sato et al. (2003b) reported that TRAF6 is involved in TRIF mediated IRF3 activation and NF- $\mathrm{B}$ activation during TLR signaling. However, a recent paper delineated the involvement of TRAF6 in TLR signaling, where TRAF6 is involved in MyD88 mediated NF- $\kappa B$ activation but not TRIF mediated NF- $\mathrm{KB}$ activation (Gohda et al., 2004).

\section{Transcription factors activated by TLR engagement}

PAMPs stimulation through TLR-dependent and independent pathways converges at the activation of transcription factors NF- $\mathrm{B}, \mathrm{IRF} / 7 / 5$, and/or $A P-1$. These transcription factors collaborate with each other to produce a large number of cytokines, which are barely detectable in resting cells. The multi-transcription factor binding sites in the promoter of a given gene lead to this highly specific activation. The multistage gene regulation by this interaction and the specific transcription factors activated will be discussed below. 


\section{NF-KB as double edged sword}

The continued research on TLRs has led to the delineation of specificity in the regulation and interaction of transcription factors upon stimulation leading to a highly specific gene expression. NF$\kappa B$ is the major transcription factor which functions on TLR signaling to control/elicit inflammation. $N F-\kappa B$ was first described as a $B$ cell specific transcription factor that binds the $\kappa B$ site in the $\lg \kappa$ light chain enhancer (Sen and Baltimore, 1986). Viral promoters contain NF-kB binding sites making it advantageous for its replication. So it is not exaggerating to say that cells which have $N F-\kappa B$ as a sword against the viral infection turn back against to them. NF-kB has often been called a 'central mediator of the immune response'. MAL-MyD88 and TRAM-TRIF pathways stimulate NF- $k B$ activation albeit with different kinetics (Selvarajoo, 2006). NF-kB activity was found to be inducible in all cell types and it is now known that members of the NF-kB/Rel family regulate many genes involved in immune and inflammatory responses (Pahl, 1999; Hayden and Ghosh, 2004). NF-KB can be induced by a variety of stimuli (www.NF-kB.org). For example, recent studies described about the involvement of $I \mathrm{kB} \zeta$ to interact with NF-kB via a $\mathrm{C}$ terminal ankyrin repeat domain in the nucleus to induce IL-6 (Motoyama et al., 2005; Yamazaki et al., 2005). The differential interaction of transcription factors activated upon TLR stimulation is shown in Figure 4.

\section{Activating protein-1 (AP1)}

The JNK and p38 cascades are activated first and foremost in response to inflammatory cytokines, bacterial products, and various stress factors. Activation of TAK1 during TLR signaling results in the activation of MAPKs, including JNK/p38, leading to the activation of AP-1 (Ninomiya-Tsuji et al., 1999; Akira and Takeda, 2004; Sato et al., 2005), which together with NF-kB governs the production of inflammatory cytokines and chemokines (Kawai and Akira, 2006). Activation of these $\mathrm{JNK} / \mathrm{p} 38$ cascades is associated with selective activation of different AP-1 subunits and transcription factors interacting with AP-1 (Johnson and Lapadat, 2002).

For example, LPS stimulation in precursor B cells and primary dendritic cells leads to JUND and JUNB activation (Krappmann et al., 2004). The authors further show that these complex in turn are required for high-level sustained induction of chemokine receptor 7 (CCR-7) and Ig light chain

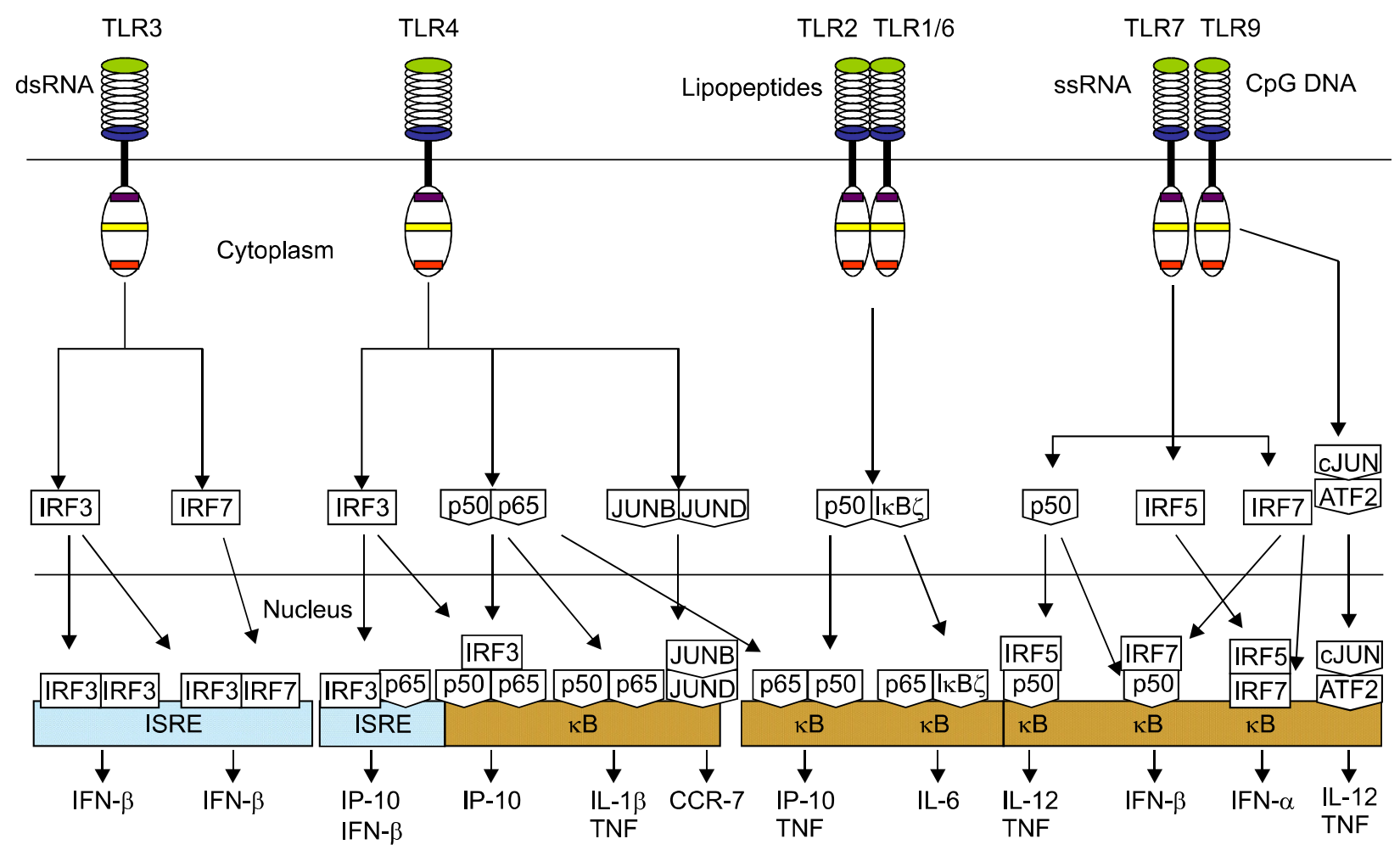

Figure 4. Interaction of transcription factors leading to a highly specific gene expression upon TLR stimulation. ISRE, interferon stimulatory response element; $\kappa B, \kappa B$ site. 
expression and production of surface IgM. On the other hand, CpG-DNA induces activation of JNK1/2 and p38 in murine macrophages and dendritic cells leading to the phosphorylation of c-JUN and ATF2 (Hacker et al., 1998). This activation via p38 is necessary for the full induction of TNF- $\alpha$ and IL-12 as inhibition of p38 abrogates this biological response. TLR2 stimulation by PAM3CSK4 in DCs leads to the enhanced induction of c-FOS and induces high production of IL-10 but low level of IL-12 (Dillon et al., 2004). All these studies together indicate that it is the differential activation and binding of AP-1 subunits which contribute to the inflammation.

\section{IRFs are the novel regulators of TLR pathway}

In recent past, attentions have been diverted to the IRF family of transcription factors which have important roles in the regulation of type I interferon production and a growing list of other genes. Our best understanding of IFN gene regulation comes from studies on TLR3 and TLR4 signaling both known to activate IRF3. The molecular mechanisms responsible for the phosphorylation induced activation of IRF3 have been the subject of intense study. IRF3 and IRF7 have recently been identified as the master regulators of type 1 IFN activation but yet many unanswered questions remain about their biology, structure, function and crosstalk with other important transcription factors. The answers to these questions will undoubtedly have important therapeutic applications for immune responses and modulation.

A major breakthrough recently implicated two IKB kinase-related kinases, IKKE (also known as IKKi) and TBK1 (TANK-binding kinase 1), in the IRF3 pathway (Fitzgerald et al., 2003; Sharma et al., 2003). TBK1 deficient embryonic fibroblasts are impaired in their ability to activate IRF3 or to induce IFN- $\beta$ in response to LPS, poly (I-C) or a variety of viruses (Hemmi et al., 2004; McWhirter et al., 2004; Perry et al., 2004). Both IKKE and TBK1 directly phosphorylate IRF3, a property not shared by either IKK $\alpha$ or IKK $\beta$ (Sharma et al., 2003; McWhirter et al., 2004). Recently, phosphatidylinositol 3-kinase has also been implicated in IRF3 activation and seems to be required for full activation of IRF3 following TLR3 signaling (Sarkar et al., 2004). However, the IFN regulation seems to differ from cell to cell. Macrophages solely utilize TLR4 for IFN production, but neither TLR3 nor TLR4 is expressed in pDCs (plasmacytoid dendritic cells), therefore, these receptors cannot account for the production of IFN in these cells (Colonna et al., 2004). TLR expression by human and mouse
pDCs is restricted to TLR7 and TLR9 making them highly specialized for the detection of viral nucleic acids (Hornung et al., 2002). Further experiments in this area would delineate the specificity of IFN production during antiviral signaling.

Stimulation via TLR3 leads to the nuclear localization of IRF3 which binds as a dimer to induce IP-10 and IFN- $\beta$ genes (Fitzgerald et al., 2003). IKK activated by TLR4 signaling activates the p65/p50 dimer (Zandi et al., 1997). IRF3 activated by TBK1 forms dimer with p65 to induce IP-10 and IFN- $\beta$ (Wietek et al., 2003) and glucocorticoids can also suppress these heterodimers (Ogawa et al., 2005). IP-10 and proinflammatory cytokines can be induced by p65/p50 dimers binding to $\mathrm{\kappa B}$ site and if IRF3 acts as a co-activator for this complex IP-10 can be induced (Leung et al., 2004).

Studies of IFN regulation also suggest that the autocrine/paracrine action of INF- $\beta$ produced by IRF3 can induce IRF7 de novo which activates IFN- $\alpha$ (Au et al., 1998; Marie et al., 1998). Regulation of IFN production via TLRs is entirely distinct in pDCs. pDCs unlike fibroblasts, epithelial and most hematopoietic cells utilize IRF7 (Colonna et al., 2004; Diebold et al., 2004; Heil et al., 2004; Krug et al., 2004). Comparison between IRF3 ${ }^{-1-}$ pDCs and IRF7 ${ }^{-1-}$ pDCs revealed that IFN production by TLR 7, 8 and 9 was normal in IRF $3^{-l-}$ cells, but completely ablated in IRF7 $7^{-1-}$ cells, indicating that IRF7 is essential for the induction of IFN- $\alpha / \beta$ genes in pDCs (Honda et al., 2005). Moreover, IRF7 was shown to be involved in the induction of $\mathrm{CD}^{+}$cells responses in pDCs (Honda et al., 2005). Hence, IRF7 seems to be a very important and novel player in the development of innate and adaptive immunity in pDCs. Mutation analysis studies showed that IFN- $\beta$ promoter also requires IRF7 for its induction.

IRF5 is shown to be activated only by certain viruses such as Newcastle Disease Virus (NDV), whereas the other virus such as Sendai Virus (SV) or dsRNA [e.g., poly (I-C)] activates IRF3 and IRF7 but not IRF 5 (Barnes et al., 2003; Elco et al., 2005). These studies indicate that IRF5 activation is restricted. However, recently Takaoka et al. (2005) have found that using hematopoietic cells from mice deficient in IRF5, the induction of inflammatory cytokines such as IL-6, IL-12 and TNF- $\alpha$ in response to the ligands of TLR4, TLR5, TLR7 and TLR9 is severely impaired. The authors suggest that putative IFN-stimulated response elements in the promoters of these inflammatory cytokines bind IRF5. Hence, this new player of TLR signaling awaits further studies to delineate its involvement in controlling inflammation. 


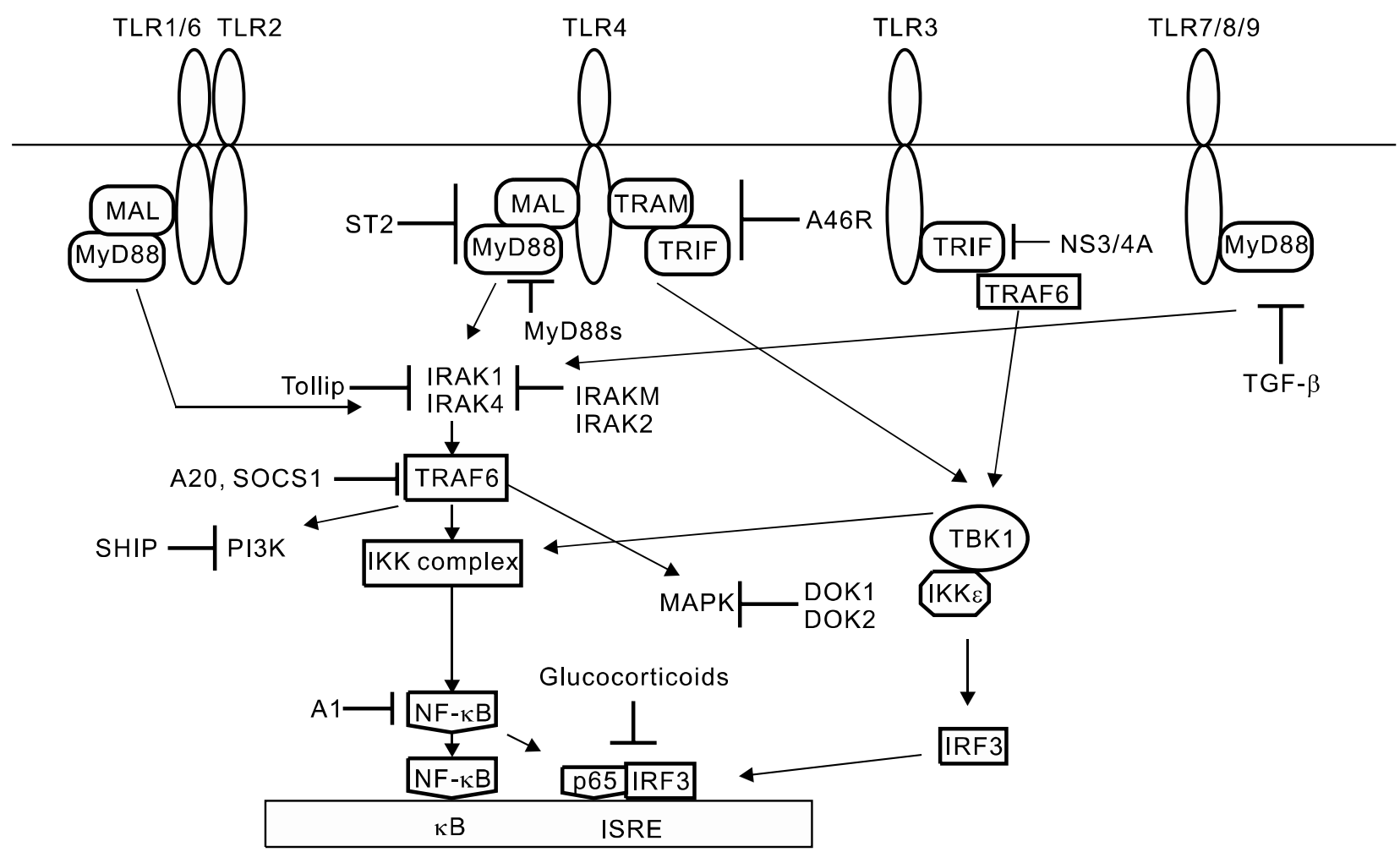

Figure 5. Negative feedback loops have evolved at different steps along the TLR pathway, all serving the same: Keeping the inflammatory responses in check. A1, BCL-2 homologue; DOK1, downstream of kinase 1; MyD88s, splice variant of MyD88; SHIP, SH2-containing inositol phosphatase; SOCS1, suppressor of cytokine signaling 1 ; ST2, suppression of tumorigenicity 2.

\section{Negative regulators of TLR signaling}

The adapters are the indispensable components of TLR signaling and appear to be Achilles' heels for both exogenous and endogenous inhibition of TLR signaling. The immune system has created checkpoints at various levels of TLR signaling that will limit the amount and/or duration of inflammatory response. Amongst the molecules under checkpoints, the adapters appear to be prone to inhibition. Figure 5 illustrates our current understanding of adaptor inhibition. ST2 (suppression of tumorigenicity 2), also called as interleukin 1 receptorlike 1 which is a member of IL-1R subgroup of TIR proteins, sequesters MAL and MyD88, thereby preventing the IL-1R and TLR4 signaling but not TLR3 signaling (Brint et al., 2004). A splice variant of MyD88, called MyD88s, acts to displace MyD88 and prevent NF-KB activation (Burns et al., 2003). MyD88s does not interact with IRAK4 because it lacks a region that is important for IRAK4 recruitment. So, IRAK4 is not recruited to the IL-1R, thereby preventing the association of IRAK1 and IRAK4 and thus the phosphorylation of IRAK1. As a result, there is no NF-kB activation. TGF- $\beta$ facilitates ubiquitination and proteasomal degradation of MyD88 and attenuates MyD88-dependent signaling by decreasing cellular levels of MyD88 protein (Naiki et al., 2005). This may be a key aspect of the anti-inflammatory effects of TGF- $\beta$.

Viruses also target adapters, thus limiting TLR signal transduction to modulate immune responses. Vaccinia virus $A 46 \mathrm{R}$ can block both IL-1 and TLR4 signaling (Bowie et al., 2000). A46R is in fact an inhibitor of multiple TIR adapters by sequestering MyD88, MAL, TRAM and TRIF (Stack et al., 2005). Another important observation is that the hepatitis $C$ virus protein NS3/4A causes specific proteolysis of TRIF, an adaptor protein linking TLR3 to kinases responsible for activating transcription factors controlling a multiplicity of antiviral defenses (Li et al., 2005). This limits the induction of IFN- $\beta$ by TLR3 during infection and might contribute to the persistence of the virus. Viruses have therefore evolved mechanisms to target adapters in TLR signaling, pointing to the importance of TLRs in antiviral immunity.

In endothelial cells the zinc finger protein A20 inhibits activation of TRAF6 by interfering with NF-KB signaling (Heyninck and Beyaert, 1999). A1 (BCL-2 homologue) also inhibits NF-KB activation but this process is a little ambiguous (Karsan et al., 1996). A1 and A20 provide negative feedback 
Table 3. Collaboration of TLRs with other receptors.

\begin{tabular}{ll}
\hline \multicolumn{1}{c}{ Interacting receptor } & \multicolumn{1}{c}{ Function of the interacting receptor } \\
\hline Dectins & Aids in phagocytosis of zymosan \\
Integrins & CR3 binds with LPS \\
Scavenger receptors & Induced by TLR, phagocytosis of $E$. coli \\
Fc gamma R & Anti-inflammatory/inhibition of TLR mediated IL-12 production \\
MD2 & Interact with TLR4 for LPS recognition \\
Card like helicases & Enhanced antiviral responses \\
NODs & Enhanced antiviral responses \\
NALPs & Augmented inflammatory responses \\
GPCRs and TLRs & Increased polymorphonuclear leukocyte (PMN) migration \\
Adenosine receptors and TLRs & Angiogenesis \\
\hline
\end{tabular}

signaling for TLR4 as both of them can be up-regulated by LPS induced NF- $\mathrm{NB}$ signaling. PI3K plays dual roles after activated from TRAF6 as both positive and negative regulator of signaling. SHIP (SH2-containing inositol phosphatase) can inhibit PI3K signaling (Liu et al., 1999). TRAF6 and IRAK association is prevented by IRAKM (Kobayashi et al., 2002). LPS induced ERK activation is prevented by the inhibitory adapter DOK1 (downstream of kinase 1) and DOK2 (Shinohara et al., 2005). SOCS1 (suppressor of cytokine signaling 1) has been reported to be rapidly induced by LPS and negatively regulate LPS signaling, suggesting the suppression of TRAF6 (Kinjyo et al., 2002). These studies indicate that it might be possible to design selective inhibitors of adapters that might be used therapeutically.

\section{Collaboration and crosstalk of TLRs with other receptors and pathways}

TGF- $\beta$ signaling modulates LPS-induced NF- $\kappa B$ activation, cytokine release, and suppression of inflammation through MyD88 which is a specific target of TGF- $\beta$ and reveals novel signaling crosstalk interactions between TGF- $\beta$ and TLR signaling (Naiki et al., 2005). The authors further showed that TGF- $\beta$ potently inhibited LPS-induced $N F-\kappa B$ activation and TNF- $\alpha$ release from RAW 264.7 cells but had no effect on IFN- $\beta$ promoter activation or RANTES (regulated upon activation, normal T-cell expressed, and secreted) release, indicating that MyD88-dependent pathway is inferred but not the MyD88-independent pathway downstream of TLRs. Ramification of cAMP pathway contributes to the diversity of signaling pathways and PKA phosphorylates p38 with a delayed kinetics forming the crosstalk point between $G$ protein coupled receptors and TLRs
(Delghandi et al., 2005) (Table 3). p38 which is activated through TLR can also phosphorylate STAT1 forming another crosstalk with IFN signaling pathways (Dalpke et al., 2003).

There is a synergistic effect of TLR to induce its neighbors upon appropriate stimulation. For instance, given the effective immune modulation by CpG DNA, regulation of TLR9 expression might play an important role in controlling the overall responses of immune cells to bacteria. When stimulated with TLR4 ligand LPS, macrophages increase TLR9, and thus respond to CpG DNA more effectively (An et al., 2002).

\section{Systems biology approach to TLR4 signaling}

So far, we have discussed about the main players of the TLR pathways through the sequential signaling process. In reality, however, the signaling behavior is highly complex (Oda and Kitano, 2006) due to the dynamical interaction of the various intracellular molecules and pathways. To approach the non-intuitive character of signaling pathways, we therefore require systematic methodologies that incorporate both biological and theoretical methods to interpret signaling dynamics (Gilchrist et al., 2006; Markevich et al., 2006; Selvarajoo, 2006; Alon, 2007; Basak et al., 2007; Kholodenko, 2007). Recently, there have been such attempts to understand the signaling dynamics of TLRs (Covert et al., 2005; Selvarajoo, 2006). The results of these studies have systematically revealed some important findings regarding the behavior of TLR pathways, not intuitively understood. For example, we demonstrated the delayed activation of NF- $\mathrm{B}$ observed in MyD88 knock-out mice is due to both slower kinetics and missing intermediates acting along the TRIF-dependent pathways (Selvarajoo, 


\author{
Adaptive immune responses \\ Innate immune responses \\ Detection of tissue injury \\ Tissue remodeling and repair \\ Chemotherapy \\ Vaccine Strategies
}

Physiology

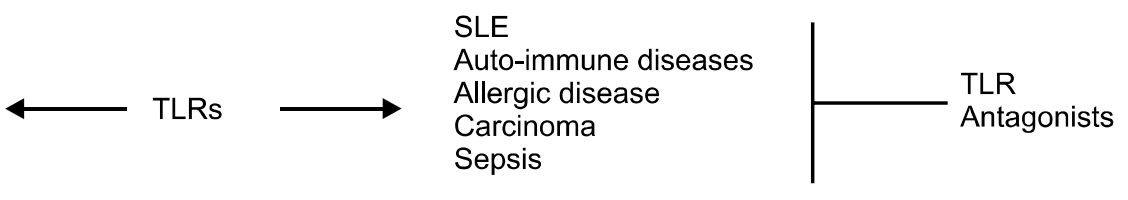

Pathology

Figure 6. The physiological and pathological effects of TLR stimulation. TLRs have bi-functions and play roles in both physiological responses to pathogen as well as pathology in various diseases.

2006).

On a global front, the analysis of high throughput experimental data has demonstrated more detailed understanding of large scale gene expressions in innate immune system (Ricciardi-Castagnoli and Granucci, 2002; Zhu et al., 2004, 2006; Hirotani et al., 2005; Nilsson et al., 2006). Despite this, we are yet to have a comprehensive view of TLR signaling events due to the lack of understanding in the interplay between the dynamics of gene regulatory networks and signaling pathways. For example, in LPS stimulation the secondary effects such as miRNA regulation (Taganov et al., 2007) or autocrine/paracrine signaling (e.g., TNF- $\alpha$ signaling) after a few of hours of stimulation are not clearly understood. This is perhaps one of the reasons for the failure of the development of drug target for any specific pathways in controlling inflammatory diseases. Therefore, the development, integration and use of systems biology approaches will be necessary for deeper knowledge of TLR signaling pathway.

\section{TLRs in physiology and pathology: TLRs and immune disorders}

The role played by TLRs in various physiological and pathological conditions is shown in Figure 6. Impaired vaccine responses and increased morbidity and mortality in aged humans $(65<)$ were associated with $36 \%$ decreased surface expression of TLR1 compared with young adults (Duin et al., 2007). Certain TLRs expressions are implicated in laryngeal carcinoma (Szczepanski et al., 2007). During diabetes in mice, augmented TNF- $\alpha$ production by LPS in macrophages was due to hyperglycemia and increased activation of p38 kinase (Sherry et al., 2007). Chemokines and TLRs are important signals in macrophage mediated recognition and rejection of islet xenografts (Chandra et al., 2007). In patients with active SLE (systemic lupus erythematosus), the proportion of peripheral blood memory $B$ cells and plasma cells expressing TLR9 is increased. Endogenous nucleic acids released during apoptotic cell death may stimulate B cells via TLR9 and contribute to SLE pathogenesis (Papadimitraki et al., 2006).

Interestingly a role of TLRs in exercise is also reported. Cell surface expressions of TLRs are reported to be decreased after prolonged exercise contributing post-exercise immunodepression and the reported higher susceptibility to infection in athletes (Gleeson et al., 2006). The precise physiological stimulus mediating an exercise-induced decrease in cell-surface TLR expression is not known. However, a number of possible signals have been implicated including anti-inflammatory cytokines, stress hormones and heat shock proteins. TLR ligands are considered as adjuvants for immunotherapy since $\mathrm{CD}^{+}{ }^{+}$effector cells can constitutively express TLR3 and produce IFN- $\gamma$ upon poly (I-C) stimulation, which may lead to better responses against tumors or chronic viral infections (Tabiasco et al., 2006). TLR4 promotes the trapping of activated $\mathrm{CD8}^{+} \mathrm{T}$ cells in the liver (Komatsu et al., 2000; John et al., 2007) and without TLR4, the liver trapped fewer activated $\mathrm{CD}^{+}{ }^{+}$cells, leading to an increase of these cells in the circulation. Hyperthermia $\left(39.5^{\circ} \mathrm{C}\right)$ during fever might activate innate immune response by promoting TLR4 expression and signaling but not TLR2 expression (Zhao et al., 2007). TLR-mediated induction of type I IFNs and soluble adhesion molecules such as sE-selectin (soluble form of E-selectin) and SICAM (soluble intercellular adhesion molecule) in sera are shown to be operative in retinal vascular endothelial cells (Lee et al., 2007). Taken together, all these studies indicate that the old dogma of TLRs would span across the fields of immunity.

\section{Future researches}

Though we have come across a lot of information from the remarkable progress which has been made since the discovery of TLRs, yet, many unanswered questions remain. For instance, 
whether TLRs can directly recognize their ligands as some studies suggest (Lien et al., 2000; Poltorak et al., 2000; Sato et al., 2003a) or whether an accessory molecule like MD2 or an intermediary similar to Drosophila extracellular protein Spatzle performs this function (Akashi et al., 2001; Medzhitov, 2001; Hoffman and Reichhart, 2002). The another intriguing question with TLRs is how the innate immune system manages to recognize synthetic CpG oligonucleotides and bacterial DNA against a possible background of host DNA set generated through trauma, apoptosis or other events that liberate host DNA inside the body. Although a consistent view of the TLR-signaling mechanism is emerging from biochemical and biophysical studies, there is a lack of detailed structural information on the macromolecular complexes involved in the signaling process.

Since the innate immune system is highly complex, systems biological approaches are going to play an ever increasing role to provide understanding of innate immune dynamic regulation. More information of the above mentioned lacunas through continued researches on TLRs will add more understanding in this aspect and help to develop therapeutics in the clearance of pathogen, which is what we can wish for.

\section{Acknowledgement}

This work was supported by the Korea Research Foundation Grant funded by the Korean Government (MOEHRD) (KRF-2006-311-C00482), and 2006 Ajou University Internal Research Grant to S.C. Krishnan was supported by BK21 program.

\section{References}

Akashi S, Nagai Y, Ogata H, Oikawa M, Fukase K, Kusumoto S, Kawasaki K, Nishijima M, Hayashi S, Kimoto M, Miyake K. Human MD-2 confers on mouse Toll-like receptor 4 species-specific lipopolysaccharide recognition. Int Immunol 2001;13:1595-9

Akira S, Takeda K, Kaisho T. Toll-like receptors: critical proteins linking innate and acquired immunity. Nat Immunol 2001;2:675-80

Akira S, Takeda K. Toll-like receptor signalling. Nat Rev Immunol 2004;4:499-511

Alexopoulou L, Holt AC, Medzhitov R, Flavell RA. Recognition of double-stranded RNA and activation of NF-kappaB by Toll-like receptor 3. Nature 2001;413:732-8

Alon U. Network motifs: theory and experimental approaches. Nat Rev Genet 2007;8:450-61

An H, Xu H, Yu Y, Zhang M, Qi R, Yan X, Liu S, Wang W, Guo
Z, Qin Z, Cao X. Up-regulation of TLR9 gene expression by LPS in mouse macrophages via activation of NF-kappaB, ERK and p38 MAPK signal pathways. Immunol Lett 2002;81:165-9

Au WC, Moore PA, LaFleur DW, Tombal B, Pitha PM. Characterization of the interferon regulatory factor-7 and its potential role in the transcription activation of interferon $A$ genes. J Biol Chem 1998;273:29210-7

Barnes BJ, Kellum MJ, Pinder KE, Frisancho JA, Pitha PM. Interferon regulatory factor 5 , a novel mediator of cell cycle arrest and cell death. Cancer Res 2003;63:6424-31

Barton GM, Kagan JC, Medzhitov R. Intracellular localization of Toll-like receptor 9 prevents recognition of self DNA but facilitates access to viral DNA. Nat Immunol 2006;7:49-56

Basak S, Kim H, Kearns JD, Tergaonkar V, O'Dea E, Werner SL, Benedict CA, Ware CF, Ghosh G, Verma IM, Hoffmann A. A fourth IkappaB protein within the NF-kappaB signaling module. Cell 2007;128:369-81

Becker MN, Diamond G, Verghese MW, Randell SH. CD14-dependent lipopolysaccharide-induced beta-defensin-2 expression in human tracheobronchial epithelium. J Biol Chem 2000;275:29731-6

Bin LH, Xu LG, Shu HB. TIRP, a novel Toll/interleukin-1 receptor (TIR) domain-containing adapter protein involved in TIR signaling. J Biol Chem 2003;278:24526-32

Bowie A, Kiss-Toth E, Symons JA, Smith GL, Dower SK, O'Neill LA. A46R and A52R from vaccinia virus are antagonists of host IL-1 and toll-like receptor signaling. Proc Natl Acad Sci USA 2000;97:10162-7

Brint EK, Xu D, Liu H, Dunne A, McKenzie AN, O'Neill LA, Liew FY. ST2 is an inhibitor of interleukin 1 receptor and Toll-like receptor 4 signaling and maintains endotoxin tolerance. Nat Immunol 2004;5:373-9

Burns K, Janssens S, Brissoni B, Olivos N, Beyaert R, Tschopp J. Inhibition of interleukin 1 receptor/Toll-like receptor signaling through the alternatively spliced, short form of MyD88 is due to its failure to recruit IRAK-4. J Exp Med 2003;197:263-8

Cario E, Rosenberg IM, Brandwein SL, Beck PL, Reinecker HC, Podolsky DK. Lipopolysaccharide activates distinct signaling pathways in intestinal epithelial cell lines expressing Toll-like receptors. J Immunol 2000;164:966-72

Chamaillard M, Hashimoto M, Horie Y, Masumoto J, Qiu S, Saab L, Ogura Y, Kawasaki A, Fukase K, Kusumoto S, Valvano MA, Foster SJ, Mak TW, Nunez G, Inohara N. An essential role for NOD1 in host recognition of bacterial peptidoglycan containing diaminopimelic acid. Nat Immunol 2003;4:702-7

Chandra AP, Ouyang L, Yi S, Wong JK, Ha H, Walters SN, Patel AT, Stokes R, Jardine M, Hawthorne WJ, O'Connell PJ. Chemokine and toll-like receptor signaling in macrophage mediated islet xenograft rejection. Xenotransplantation 2007;14:48-59

Chen ZJ. Ubiquitin signalling in the NF-kappaB pathway. Nat Cell Biol 2005;7:758-65

Colonna M, Trinchieri G, Liu YJ. Plasmacytoid dendritic cells 
in immunity. Nat Immunol 2004;5:1219-26

Covert MW, Leung TH, Gaston JE, Baltimore D. Achieving stability of lipopolysaccharide-induced NF-kappaB activation. Science 2005;309:1854-7

Dalpke AH, Eckerle S, Frey M, Heeg K. Triggering of Toll-like receptors modulates IFN-gamma signaling: involvement of serine 727 STAT1 phosphorylation and suppressors of cytokine signaling. Eur J Immunol 2003;33:1776-87

Delghandi MP, Johannessen M, Moens U. The cAMP signalling pathway activates CREB through PKA, p38 and MSK1 in NIH 3T3 cells. Cell Signal 2005;17:1343-51

Diebold SS, Kaisho T, Hemmi H, Akira S, Reis e Sousa C. Innate antiviral responses by means of TLR7-mediated recognition of single-stranded RNA. Science 2004;303: 1529-31

Dillon S, Agrawal A, Van Dyke T, Landreth G, McCauley L, Koh A, Maliszewski C, Akira S, Pulendran B. A Toll-like receptor 2 ligand stimulates Th2 responses in vivo, via induction of extracellular signal-regulated kinase mitogenactivated protein kinase and c-Fos in dendritic cells. J Immunol 2004;172:4733-43

Duin D, Mohanty S, Thomas V, Ginter S, Montgomery RR, Fikrig E, Allore HG, Medzhitov R, Shaw AC. Age-associated defect in human TLR-1/2 function. J Immunol 2007;178: 970-5

Elco CP, Guenther JM, Williams BR, Sen GC. Analysis of genes induced by Sendai virus infection of mutant cell lines reveals essential roles of interferon regulatory factor 3 , NF-kappaB, and interferon but not toll-like receptor 3. J Virol 2005;79:3920-9

Equils O, Madak Z, Liu C, Michelsen KS, Bulut Y, Lu D. Rac1 and Toll-IL-1 receptor domain-containing adapter protein mediate Toll-like receptor 4 induction of HIV-long terminal repeat. J Immunol 2004;172:7642-6

Faure E, Thomas L, Xu H, Medvedev A, Equils O, Arditi M. Bacterial lipopolysaccharide and IFN-gamma induce Tolllike receptor 2 and Toll-like receptor 4 expression in human endothelial cells: role of NF-kappa B activation. J Immunol 2001;166:2018-24

Fitzgerald KA, Palsson-McDermott EM, Bowie AG, Jefferies CA, Mansell AS, Brady G, Brint E, Dunne A, Gray P, Harte MT, McMurray D, Smith DE, Sims JE, Bird TA, O'Neill LA. Mal (MyD88-adapter-like) is required for Toll-like receptor-4 signal transduction. Nature 2001;413:78-83

Fitzgerald KA, McWhirter SM, Faia KL, Rowe DC, Latz E, Golenbock DT, Coyle AJ, Liao SM, Maniatis T. IKKepsilon and TBK1 are essential components of the IRF3 signaling pathway. Nat Immunol 2003;4:491-6

Garlanda C, Bottazzi B, Bastone A, Mantovani A. Pentraxins at the crossroads between innate immunity, inflammation, matrix deposition, and female fertility. Annu Rev Immunol 2005;23:337-66

Gasque P. Complement: a unique innate immune sensor for danger signals. Mol Immunol 2004;41:1089-98

Gay NJ, Keith FJ. Drosophila Toll and IL-1 receptor. Nature 1991;351:355-6
Gilchrist M, Thorsson V, Li B, Rust AG, Korb M, Kennedy K, Hai T, Bolouri H, Aderem A. Systems biology approaches identify ATF3 as a negative regulator of Toll-like receptor 4. Nature 2006;441:173-8

Girardin SE, Boneca IG, Viala J, Chamaillard M, Labigne A, Thomas G, Philpott DJ, Sansonetti PJ. Nod2 is a general sensor of peptidoglycan through muramyl dipeptide (MDP) detection. J Biol Chem 2003;278:8869-72

Gleeson M, McFarlin B, Flynn M. Exercise and Toll-like receptors. Exerc Immunol Rev 2006;12:34-53

Gohda J, Matsumura T, Inoue J. Cutting edge: TNFRassociated factor (TRAF) 6 is essential for MyD88-dependent pathway but not toll/IL-1 receptor domaincontaining adaptor-inducing IFN-beta (TRIF)-dependent pathway in TLR signaling. J Immunol 2004;173:2913-7

Habich C, Baumgart K, Kolb H, Burkart V. The receptor for heat shock protein 60 on macrophages is saturable, specific, and distinct from receptors for other heat shock proteins. J Immunol 2002;168:569-76

Hacker H, Mischak H, Miethke T, Liptay S, Schmid R, Sparwasser T, Heeg K, Lipford GB, Wagner H. CpGDNA-specific activation of antigen-presenting cells requires stress kinase activity and is preceded by non-specific endocytosis and endosomal maturation. Embo J 1998;17: 6230-40

Han KJ, Su X, Xu LG, Bin LH, Zhang J, Shu HB. Mechanisms of the TRIF-induced interferon-stimulated response element and NF-kappaB activation and apoptosis pathways. J Biol Chem 2004;279:15652-61

Hashimoto C, Hudson KL, Anderson KV. The Toll gene of Drosophila, required for dorsal-ventral embryonic polarity, appears to encode a transmembrane protein. Cell 1988;52:269-79

Hayashi F, Smith KD, Ozinsky A, Hawn TR, Yi EC, Goodlett DR, Eng JK, Akira S, Underhill DM, Aderem A. The innate immune response to bacterial flagellin is mediated by Toll-like receptor 5. Nature 2001;410:1099-103

Hayden MS, Ghosh S. Signaling to NF-kappaB. Genes Dev 2004;18:2195-224

Heil F, Hemmi H, Hochrein H, Ampenberger F, Kirschning C, Akira S, Lipford G, Wagner H, Bauer S. Species-specific recognition of single-stranded RNA via toll-like receptor 7 and 8. Science 2004;303:1526-9

Hemmi H, Takeuchi O, Kawai T, Kaisho T, Sato S, Sanjo H, Matsumoto M, Hoshino K, Wagner H, Takeda K, Akira S. A Toll-like receptor recognizes bacterial DNA. Nature 2000;408:740-5

Hemmi H, Kaisho T, Takeuchi O, Sato S, Sanjo H, Hoshino $\mathrm{K}$, Horiuchi T, Tomizawa H, Takeda K, Akira S. Small anti-viral compounds activate immune cells via the TLR7 MyD88dependent signaling pathway. Nat Immunol 2002;3: 196-200

Hemmi H, Takeuchi O, Sato S, Yamamoto M, Kaisho T, Sanjo H, Kawai T, Hoshino K, Takeda K, Akira S. The roles of two IkappaB kinase-related kinases in lipopolysaccharide and double stranded RNA signaling and viral infection. J Exp Med 2004;199:1641-50 
Heyninck K, Beyaert R. The cytokine-inducible zinc finger protein A20 inhibits IL-1-induced NF-kappaB activation at the level of TRAF6. FEBS Lett 1999;442:147-50

Hirotani T, Yamamoto M, Kumagai Y, Uematsu S, Kawase I, Takeuchi O, Akira S. Regulation of lipopolysaccharideinducible genes by MyD88 and Toll/IL-1 domain containing adaptor inducing IFN-beta. Biochem Biophys Res Commun 2005;328:383-92

Hoebe K, Du X, Georgel P, Janssen E, Tabeta K, Kim SO, Goode J, Lin P, Mann N, Mudd S, Crozat K, Sovath S, Han $\mathrm{J}$, Beutler B. Identification of Lps2 as a key transducer of MyD88-independent TIR signalling. Nature 2003;424:743-8

Hoffmann JA, Reichhart JM. Drosophila innate immunity: an evolutionary perspective. Nat Immunol 2002;3:121-6

Honda K, Yanai H, Negishi H, Asagiri M, Sato M, Mizutani T, Shimada N, Ohba Y, Takaoka A, Yoshida N, Taniguchi T. IRF-7 is the master regulator of type-I interferon-dependent immune responses. Nature 2005;434:772-7

Horng T, Barton GM, Flavell RA, Medzhitov R. The adaptor molecule TIRAP provides signalling specificity for Toll-like receptors. Nature 2002;420:329-33

Hornung V, Rothenfusser S, Britsch S, Krug A, Jahrsdorfer B, Giese T, Endres S, Hartmann G. Quantitative expression of toll-like receptor 1-10 mRNA in cellular subsets of human peripheral blood mononuclear cells and sensitivity to CpG oligodeoxynucleotides. J Immunol 2002;168:4531-7

Hornung V, Guenthner-Biller M, Bourquin C, Ablasser A, Schlee M, Uematsu S, Noronha A, Manoharan M, Akira S, de Fougerolles A, Endres S, Hartmann G. Sequencespecific potent induction of IFN-alpha by short interfering RNA in plasmacytoid dendritic cells through TLR7. Nat Med 2005; $11: 263-70$

Hoshino K, Takeuchi O, Kawai T, Sanjo H, Ogawa T, Takeda Y, Takeda K, Akira S. Cutting edge: Toll-like receptor 4 (TLR4)-deficient mice are hyporesponsive to lipopolysaccharide: evidence for TLR4 as the Lps gene product. J Immunol 1999;162:3749-52

Inohara N, Ogura Y, Fontalba A, Gutierrez O, Pons F, Crespo J, Fukase K, Inamura S, Kusumoto S, Hashimoto M, Foster SJ, Moran AP, Fernandez-Luna JL, Nunez G. Host recognition of bacterial muramyl dipeptide mediated through NOD2. Implications for Crohn's disease. J Biol Chem 2003;278:5509-12

Jeyaseelan S, Young SK, Fessler MB, Liu Y, Malcolm KC, Yamamoto M, Akira S, Worthen GS. Toll/IL-1 receptor domain-containing adaptor inducing IFN-beta (TRIF)mediated signaling contributes to innate immune responses in the lung during Escherichia coli pneumonia. J Immunol 2007;178:3153-60

John B, Klein I, Crispe IN. Immune role of hepatic TLR-4 revealed by orthotopic mouse liver transplantation. Hepatology 2007;45:178-86

Johnson GL, Lapadat R. Mitogen-activated protein kinase pathways mediated by ERK, JNK, and p38 protein kinases. Science 2002;298:1911-2

Judge $A D$, Sood V, Shaw JR, Fang D, McClintock K,
MacLachlan I. Sequence-dependent stimulation of the mammalian innate immune response by synthetic siRNA. Nat Biotechnol 2005;23:457-62

Jurk M, Heil F, Vollmer J, Schetter C, Krieg AM, Wagner H, Lipford G, Bauer S. Human TLR7 or TLR8 independently confer responsiveness to the antiviral compound R-848. Nat Immunol 2002;3:499

Kagan JC, Medzhitov R. Phosphoinositide-mediated adaptor recruitment controls Toll-like receptor signaling. Cell 2006;125:943-55

Karsan A, Yee E, Harlan JM. Endothelial cell death induced by tumor necrosis factor-alpha is inhibited by the Bcl-2 family member, A1. J Biol Chem 1996;271:27201-4

Kawai T, Adachi O, Ogawa T, Takeda K, Akira S. Unresponsiveness of MyD88-deficient mice to endotoxin. Immunity 1999;11:115-22

Kawai T, Takeuchi O, Fujita T, Inoue J, Muhlradt PF, Sato S, Hoshino K, Akira S. Lipopolysaccharide stimulates the MyD88-independent pathway and results in activation of IFN-regulatory factor 3 and the expression of a subset of lipopolysaccharide-inducible genes. J Immunol 2001;167: 5887-94

Kawai T, Sato S, Ishii KJ, Coban C, Hemmi H, Yamamoto M, Terai K, Matsuda M, Inoue J, Uematsu S, Takeuchi O, Akira $\mathrm{S}$. Interferon-alpha induction through Toll-like receptors involves a direct interaction of IRF7 with MyD88 and TRAF6. Nat Immunol 2004;5:1061-8

Kawai T, Akira S. Innate immune recognition of viral infection. Nat Immunol 2006;7:131-7

Kawasaki K, Akashi S, Shimazu R, Yoshida T, Miyake K, Nishijima M. Mouse toll-like receptor 4.MD-2 complex mediates lipopolysaccharide-mimetic signal transduction by taxol. J Biol Chem 2000;275:2251-4

Kholodenko BN. Untangling the signalling wires. Nat Cell Biol 2007;9:247-9

Kinjyo I, Hanada T, Inagaki-Ohara K, Mori H, Aki D, Ohishi $M$, Yoshida $H$, Kubo M, Yoshimura A. SOCS1/JAB is a negative regulator of LPS-induced macrophage activation. Immunity 2002;17:583-91

Kobayashi K, Hernandez LD, Galan JE, Janeway CA Jr, Medzhitov R, Flavell RA. IRAK-M is a negative regulator of Toll-like receptor signaling. Cell 2002;110:191-202

Komatsu S, Berg RD, Russell JM, Nimura Y, Granger DN. Enteric microflora contribute to constitutive ICAM-1 expression on vascular endothelial cells. Am J Physiol Gastrointest Liver Physiol 2000;279:G186-91

Krappmann D, Wegener E, Sunami Y, Esen M, Thiel A, Mordmuller B, Scheidereit C. The IkappaB kinase complex and NF-kappaB act as master regulators of lipopolysaccharide-induced gene expression and control subordinate activation of AP-1. Mol Cell Biol 2004;24:6488-500

Krug A, French AR, Barchet W, Fischer JA, Dzionek A, Pingel JT, Orihuela MM, Akira S, Yokoyama WM, Colonna M. TLR9-dependent recognition of MCMV by IPC and DC generates coordinated cytokine responses that activate antiviral NK cell function. Immunity 2004;21:107-19 
Kurt-Jones EA, Popova L, Kwinn L, Haynes LM, Jones LP, Tripp RA, Walsh EE, Freeman MW, Golenbock DT, Anderson LJ, Finberg RW. Pattern recognition receptors TLR4 and CD14 mediate response to respiratory syncytial virus. Nat Immunol 2000;1:398-401

Lee MT, Hooper LC, Kump L, Hayashi K, Nussenblatt R, Hooks JJ, Detrick B. Interferon-beta and adhesion molecules (E-selectin and s-intracellular adhesion molecule-1) are detected in sera from patients with retinal vasculitis and are induced in retinal vascular endothelial cells by Toll-like receptor 3 signalling. Clin Exp Immunol 2007;147:71-80

Leung TH, Hoffmann A, Baltimore D. One nucleotide in a kappaB site can determine cofactor specificity for NF-kappaB dimers. Cell 2004;118:453-64

Li K, Foy E, Ferreon JC, Nakamura M, Ferreon AC, Ikeda M, Ray SC, Gale M Jr, Lemon SM. Immune evasion by hepatitis $C$ virus NS3/4A protease-mediated cleavage of the Toll-like receptor 3 adaptor protein TRIF. Proc Natl Acad Sci USA 2005;102:2992-7

Li S, Strelow A, Fontana EJ, Wesche H. IRAK-4: a novel member of the IRAK family with the properties of an IRAK-kinase. Proc Natl Acad Sci USA 2002;99:5567-72

Lien E, Means TK, Heine H, Yoshimura A, Kusumoto S, Fukase K, Fenton MJ, Oikawa M, Qureshi N, Monks B, Finberg RW, Ingalls RR, Golenbock DT. Toll-like receptor 4 imparts ligand-specific recognition of bacterial lipopolysaccharide. J Clin Invest 2000;105:497-504

Liu Q, Sasaki T, Kozieradzki I, Wakeham A, Itie A, Dumont DJ, Penninger JM. SHIP is a negative regulator of growth factor receptor-mediated PKB/Akt activation and myeloid cell survival. Genes Dev 1999;13:786-91

Lord KA, Hoffman-Liebermann B, Liebermann DA. Complexity of the immediate early response of myeloid cells to terminal differentiation and growth arrest includes ICAM-1, Jun-B and histone variants. Oncogene 1990;5:387-96

Mariathasan S, Weiss DS, Newton K, McBride J, O'Rourke K, Roose-Girma M, Lee WP, Weinrauch Y, Monack DM, Dixit VM. Cryopyrin activates the inflammasome in response to toxins and ATP. Nature 2006;440:228-32

Marie I, Durbin JE, Levy DE. Differential viral induction of distinct interferon-alpha genes by positive feedback through interferon regulatory factor-7. Embo J 1998;17:6660-9

Markevich NI, Tsyganov MA, Hoek JB, Kholodenko BN. Long-range signaling by phosphoprotein waves arising from bistability in protein kinase cascades. Mol Syst Biol 2006;2:61

McDonald DR, Brown D, Bonilla FA, Geha RS. Interleukin receptor-associated kinase-4 deficiency impairs Toll-like receptor-dependent innate antiviral immune responses. J Allergy Clin Immunol 2006;118:1357-62

McGettrick AF, O'Neill LA. The expanding family of MyD88-like adaptors in Toll-like receptor signal transduction. Mol Immunol 2004;41:577-82

McWhirter SM, Fitzgerald KA, Rosains J, Rowe DC, Golenbock DT, Maniatis T. IFN-regulatory factor 3-dependent gene expression is defective in Tbk1-deficient mouse embryonic fibroblasts. Proc Natl Acad Sci USA 2004; 101:233-8

Medzhitov R. Toll-like receptors and innate immunity. Nat Rev Immunol 2001;1:135-45

Motoyama M, Yamazaki S, Eto-Kimura A, Takeshige K, Muta T. Positive and negative regulation of nuclear factor-kappaBmediated transcription by IkappaB-zeta, an inducible nuclear protein. J Biol Chem 2005;280:7444-51

Muzio M, Bosisio D, Polentarutti N, D'Amico G, Stoppacciaro A, Mancinelli R, van't Veer C, Penton-Rol G, Ruco LP, Allavena $P$, Mantovani A. Differential expression and regulation of toll-like receptors (TLR) in human leukocytes: selective expression of TLR3 in dendritic cells. J Immunol 2000;164:5998-6004

Naiki Y, Michelsen KS, Zhang W, Chen S, Doherty TM, Arditi $M$. Transforming growth factor-beta differentially inhibits MyD88-dependent, but not TRAM- and TRIF-dependent, lipopolysaccharide-induced TLR4 signaling. J Biol Chem 2005;280:5491-5

Nilsson R, Bajic VB, Suzuki H, di Bernardo D, Bjorkegren J, Katayama S, Reid JF, Sweet MJ, Gariboldi M, Carninci P, Hayashizaki Y, Hume DA, Tegner J, Ravasi T. Transcriptional network dynamics in macrophage activation. Genomics 2006;88:133-42

Ninomiya-Tsuji J, Kishimoto K, Hiyama A, Inoue J, Cao Z, Matsumoto $\mathrm{K}$. The kinase TAK1 can activate the NIK-I kappaB as well as the MAP kinase cascade in the IL-1 signalling pathway. Nature 1999;398:252-6

Oda K, Kitano H. A comprehensive map of the toll-like receptor signaling network. Mol Syst Biol 2006;2:2006.0015

Ogawa S, Lozach J, Benner C, Pascual G, Tangirala RK, Westin S, Hoffmann A, Subramaniam S, David M, Rosenfeld MG, Glass CK. Molecular determinants of crosstalk between nuclear receptors and toll-like receptors. Cell 2005;122: 707-21

Ohashi K, Burkart V, Flohe S, Kolb H. Cutting edge: heat shock protein 60 is a putative endogenous ligand of the toll-like receptor-4 complex. J Immunol 2000;164:558-61

Okamura Y, Watari M, Jerud ES, Young DW, Ishizaka ST, Rose J, Chow JC, Strauss JF 3rd. The extra domain A of fibronectin activates Toll-like receptor 4 . J Biol Chem 2001;276:10229-33

Oshiumi H, Sasai M, Shida K, Fujita T, Matsumoto M, Seya T. TIR-containing adapter molecule (TICAM)-2, a bridging adapter recruiting to toll-like receptor 4 TICAM-1 that induces interferon-beta. J Biol Chem 2003;278:49751-62

Ozinsky A, Underhill DM, Fontenot JD, Hajjar AM, Smith KD, Wilson CB, Schroeder L, Aderem A. The repertoire for pattern recognition of pathogens by the innate immune system is defined by cooperation between toll-like receptors. Proc Natl Acad Sci USA 2000;97:13766-71

Pahl HL. Activators and target genes of Rel/NF-kappaB transcription factors. Oncogene 1999;18:6853-66

Papadimitraki ED, Choulaki C, Koutala E, Bertsias G, Tsatsanis C, Gergianaki I, Raptopoulou A, Kritikos HD, Mamalaki C, Sidiropoulos P, Boumpas DT. Expansion of 
toll-like receptor 9-expressing $B$ cells in active systemic lupus erythematosus: implications for the induction and maintenance of the autoimmune process. Arthritis Rheum 2006;54:3601-11

Perry AK, Chow EK, Goodnough JB, Yeh WC, Cheng G. Differential requirement for TANK-binding kinase-1 in type I interferon responses to toll-like receptor activation and viral infection. J Exp Med 2004;199:1651-8

Poltorak A, He X, Smirnova I, Liu MY, Van Huffel C, Du X, Birdwell D, Alejos E, Silva M, Galanos C, Freudenberg M, Ricciardi-Castagnoli P, Layton B, Beutler B. Defective LPS signaling in $\mathrm{C} 3 \mathrm{H} / \mathrm{HeJ}$ and $\mathrm{C} 57 \mathrm{BL} / 10 \mathrm{ScCr}$ mice: mutations in TIr4 gene. Science 1998;282:2085-8

Poltorak A, Ricciardi-Castagnoli P, Citterio S, Beutler B. Physical contact between lipopolysaccharide and toll-like receptor 4 revealed by genetic complementation. Proc Natl Acad Sci USA 2000;97:2163-7

Ricciardi-Castagnoli P, Granucci F. Opinion: Interpretation of the complexity of innate immune responses by functional genomics. Nat Rev Immunol 2002;2:881-9

Roach JC, Glusman G, Rowen L, Kaur A, Purcell MK, Smith KD, Hood LE, Aderem A. The evolution of vertebrate Toll-like receptors. Proc Natl Acad Sci USA 2005;102:9577-82

Sarkar SN, Peters KL, Elco CP, Sakamoto S, Pal S, Sen GC. Novel roles of TLR3 tyrosine phosphorylation and PI3 kinase in double-stranded RNA signaling. Nat Struct Mol Biol 2004;11:1060-7

Sato M, Sano H, Iwaki D, Kudo K, Konishi M, Takahashi H, Takahashi T, Imaizumi H, Asai Y, Kuroki Y. Direct binding of Toll-like receptor 2 to zymosan, and zymosan-induced NF-kappa B activation and TNF-alpha secretion are down-regulated by lung collectin surfactant protein $A$. J Immunol 2003a; 171:417-25

Sato S, Sugiyama M, Yamamoto M, Watanabe Y, Kawai T, Takeda K, Akira S. Toll/IL-1 receptor domain-containing adaptor inducing IFN-beta (TRIF) associates with TNF receptor-associated factor 6 and TANK-binding kinase 1 , and activates two distinct transcription factors, NF-kappa B and IFN-regulatory factor-3, in the Toll-like receptor signaling. J Immunol 2003b;171:4304-10

Sato S, Sanjo H, Takeda K, Ninomiya-Tsuji J, Yamamoto M, Kawai T, Matsumoto K, Takeuchi O, Akira S. Essential function for the kinase TAK1 in innate and adaptive immune responses. Nat Immunol 2005;6:1087-95

Selvarajoo K. Discovering differential activation machinery of the Toll-like receptor 4 signaling pathways in MyD88 knockouts. FEBS Lett 2006;580:1457-64

Sen R, Baltimore D. Multiple nuclear factors interact with the immunoglobulin enhancer sequences. Cell 1986;46:705-16

Sharma S, tenOever BR, Grandvaux N, Zhou GP, Lin R, Hiscott J. Triggering the interferon antiviral response through an IKK-related pathway. Science 2003;300:1148-51

Sherry CL, O'Connor JC, Kramer JM, Freund GG. Augmented lipopolysaccharide-induced TNF-alpha production by peritoneal macrophages in type 2 diabetic mice is dependent on elevated glucose and requires p38 MAPK. J
Immunol 2007;178:663-70

Shinohara $H$, Inoue A, Toyama-Sorimachi N, Nagai $Y$, Yasuda T, Suzuki H, Horai R, Iwakura Y, Yamamoto T, Karasuyama H, Miyake K, Yamanashi Y. Dok-1 and Dok-2 are negative regulators of lipopolysaccharide-induced signaling. J Exp Med 2005;201:333-9

Sioud M. Induction of inflammatory cytokines and interferon responses by double-stranded and single-stranded siRNAs is sequence-dependent and requires endosomal localization. J Mol Biol 2005;348:1079-90

Sioud M, Floisand Y, Forfang L, Lund-Johansen F. Signaling through toll-like receptor $7 / 8$ induces the differentiation of human bone marrow CD34+ progenitor cells along the myeloid lineage. J Mol Biol 2006;364:945-54

Slack JL, Schooley K, Bonnert TP, Mitcham JL, Qwarnstrom EE, Sims JE, Dower SK. Identification of two major sites in the type I interleukin-1 receptor cytoplasmic region responsible for coupling to pro-inflammatory signaling pathways. J Biol Chem 2000;275:4670-8

Stack J, Haga IR, Schroder M, Bartlett NW, Maloney G, Reading PC, Fitzgerald KA, Smith GL, Bowie AG. Vaccinia virus protein A46R targets multiple Toll-like-interleukin-1 receptor adaptors and contributes to virulence. J Exp Med 2005;201:1007-18

Stark GR, Kerr IM, Williams BR, Silverman RH, Schreiber $\mathrm{RD}$. How cells respond to interferons. Annu Rev Biochem 1998;67:227-64

Sun L, Deng L, Ea CK, Xia ZP, Chen ZJ. The TRAF6 ubiquitin ligase and TAK1 kinase mediate IKK activation by BCL10 and MALT1 in T lymphocytes. Mol Cell 2004;14:289-301

Suzuki N, Suzuki S, Duncan GS, Millar DG, Wada T, Mirtsos C, Takada H, Wakeham A, Itie A, Li S, Penninger JM, Wesche $\mathrm{H}$, Ohashi PS, Mak TW, Yeh WC. Severe impairment of interleukin-1 and Toll-like receptor signalling in mice lacking IRAK-4. Nature 2002;416:750-6

Szczepanski M, Stelmachowska M, Stryczynski L, Golusinski W, Samara H, Mozer-Lisewska I, Zeromski J. Assessment of expression of toll-like receptors 2, 3 and 4 in laryngeal carcinoma. Eur Arch Otorhinolaryngol 2007;264: $525-30$

Tabiasco J, Devevre E, Rufer N, Salaun B, Cerottini JC, Speiser D, Romero P. Human effector CD8+ T lymphocytes express TLR3 as a functional coreceptor. J Immunol 2006;177:8708-13

Taganov KD, Boldin MP, Baltimore D. MicroRNAs and immunity: tiny players in a big field. Immunity 2007;26:133-7

Takaoka A, Yanai H, Kondo S, Duncan G, Negishi H, Mizutani T, Kano S, Honda K, Ohba Y, Mak TW, Taniguchi T. Integral role of IRF- 5 in the gene induction programme activated by Toll-like receptors. Nature 2005;434:243-9

Takeda K, Akira S. Toll-like receptors in innate immunity. Int Immunol 2005;17:1-14

Takeuchi O, Hoshino K, Kawai T, Sanjo H, Takada H, Ogawa T, Takeda K, Akira S. Differential roles of TLR2 and TLR4 in recognition of gram-negative and gram-positive bacterial cell wall components. Immunity 1999;11:443-51 
Takeuchi O, Kaufmann A, Grote K, Kawai T, Hoshino K, Morr $M$, Muhlradt PF, Akira S. Cutting edge: preferentially the R-stereoisomer of the mycoplasmal lipopeptide macrophage-activating lipopeptide-2 activates immune cells through a toll-like receptor 2- and MyD88-dependent signaling pathway. J Immunol 2000;164:554-7

Taylor KR, Trowbridge JM, Rudisill JA, Termeer CC, Simon JC, Gallo RL. Hyaluronan fragments stimulate endothelial recognition of injury through TLR4. J Biol Chem 2004; 279:17079-84

Taylor KR, Yamasaki K, Radek KA, Di Nardo A, Goodarzi H, Golenbock D, Beutler B, Gallo RL. Recognition of hyaluronan released in sterile injury involves a unique receptor complex dependent on TLR4, CD44 and MD-2. J Biol Chem (in press) 2007

Taylor PR, Reid DM, Heinsbroek SE, Brown GD, Gordon S, Wong SY. Dectin-2 is predominantly myeloid restricted and exhibits unique activation-dependent expression on maturing inflammatory monocytes elicited in vivo. Eur $\mathrm{J}$ Immunol 2005;35:2163-74

Thomassen E, Renshaw BR, Sims JE. Identification and characterization of SIGIRR, a molecule representing a novel subtype of the IL-1R superfamily. Cytokine 1999;11:389-99

Tsuchiya M, Piras V, Fujikawa N, Tomita M, Giuliani A, Selvarajoo K. LPS induces novel signalling pathways. Submitted.

Ulevitch RJ, Tobias PS. Receptor-dependent mechanisms of cell stimulation by bacterial endotoxin. Annu Rev Immunol 1995;13:437-57

Underhill DM, Ozinsky A, Hajjar AM, Stevens A, Wilson CB, Bassetti M, Aderem A. The Toll-like receptor 2 is recruited to macrophage phagosomes and discriminates between pathogens. Nature 1999a;401:811-5

Underhill DM, Ozinsky A, Smith KD, Aderem A. Toll-like receptor-2 mediates mycobacteria-induced proinflammatory signaling in macrophages. Proc Natl Acad Sci USA 1999b;96:14459-63

Visintin A, Mazzoni A, Spitzer JH, Wyllie DH, Dower SK, Segal DM. Regulation of Toll-like receptors in human monocytes and dendritic cells. J Immunol 2001;166:249-55

Wesche H, Henzel WJ, Shillinglaw W, Li S, Cao Z. MyD88: an adapter that recruits IRAK to the IL-1 receptor complex. Immunity 1997;7:837-47

Wiens M, Korzhev M, Krasko A, Thakur NL, Perovic-Ottstadt S, Breter HJ, Ushijima H, Diehl-Seifert B, Muller IM, Muller WE. Innate immune defense of the sponge Suberites domuncula against bacteria involves a MyD88-dependent signaling pathway. Induction of a perforin-like molecule. J Biol Chem 2005;280:27949-59
Wietek C, Miggin SM, Jefferies CA, O'Neill LA. Interferon regulatory factor-3-mediated activation of the interferonsensitive response element by Toll-like receptor (TLR) 4 but not TLR3 requires the p65 subunit of NF-kappa. J Biol Chem 2003;278:50923-31

Yamamoto M, Sato S, Hemmi H, Sanjo H, Uematsu S, Kaisho T, Hoshino K, Takeuchi O, Kobayashi M, Fujita T, Takeda K, Akira S. Essential role for TIRAP in activation of the signalling cascade shared by TLR2 and TLR4. Nature 2002;420:324-9

Yamamoto M, Sato S, Hemmi H, Hoshino K, Kaisho T, Sanjo $\mathrm{H}$, Takeuchi O, Sugiyama M, Okabe M, Takeda K, Akira S. Role of adaptor TRIF in the MyD88-independent toll-like receptor signaling pathway. Science 2003a;301:640-3

Yamamoto M, Sato S, Hemmi H, Uematsu S, Hoshino K, Kaisho T, Takeuchi O, Takeda K, Akira S. TRAM is specifically involved in the Toll-like receptor 4-mediated MyD88independent signaling pathway. Nat Immunol 2003b;4: 1144-50

Yamazaki S, Muta T, Matsuo S, Takeshige K. Stimulusspecific induction of a novel nuclear factor-kappaB regulator, IkappaB-zeta, via Toll/Interleukin-1 receptor is mediated by mRNA stabilization. J Biol Chem 2005;280:1678-87

Ye H, Arron JR, Lamothe B, Cirilli M, Kobayashi T, Shevde NK, Segal D, Dzivenu OK, Vologodskaia M, Yim M, Du K, Singh S, Pike JW, Darnay BG, Choi Y, Wu H. Distinct molecular mechanism for initiating TRAF6 signalling. Nature 2002;418:443-7

Zandi E, Rothwarf DM, Delhase M, Hayakawa M, Karin M. The IkappaB kinase complex (IKK) contains two kinase subunits, IKKalpha and IKKbeta, necessary for IkappaB phosphorylation and NF-kappaB activation. Cell 1997;91: 243-52

Zhang D, Zhang G, Hayden MS, Greenblatt MB, Bussey C, Flavell RA, Ghosh S. A toll-like receptor that prevents infection by uropathogenic bacteria. Science 2004;303: 1522-6

Zhao W, An H, Zhou J, Xu H, Yu Y, Cao X. Hyperthermia differentially regulates TLR4 and TLR2-mediated innate immune response. Immunol Lett 2007;108:137-42

Zhu X, Hart R, Chang MS, Kim JW, Lee SY, Cao YA, Mock D, Ke E, Saunders B, Alexander A, Grossoehme J, Lin KM, Yan Z, Hsueh R, Lee J, Scheuermann RH, Fruman DA, Seaman W, Subramaniam S, Sternweis P, Simon MI, Choi $S$. Analysis of the major patterns of $B$ cell gene expression changes in response to short-term stimulation with 33 single ligands. J Immunol 2004;173:7141-9

Zhu X, Chang MS, Hsueh RC, Taussig R, Smith KD, Simon MI, Choi S. Dual ligand stimulation of RAW 264.7 cells uncovers feedback mechanisms that regulate TLRmediated gene expression. J Immunol 2006;177:4299-310 